\title{
A TURIZMUS GAZDASÁGBAN BETÖLTÖTT SZEREPE ÉS IRÁNYAI MAGYARORSZÁGON A COVID-19 ELŐTT ÉS UTÁN
}

Thoughts on the time-varying water balance and water level control of Lake Balaton

\author{
CSAPÓ JÁNOS ${ }^{\mathrm{ac}}$ - LŐRINCZ KATALIN ${ }^{\mathrm{bd}}$ \\ ${ }^{a}$ Pécsi Tudományegyetem Közgazdaságtudományi Kar Marketing és Turizmus Intézet \\ ${ }^{b}$ Pannon Egyetem Gazdaságtudományi Kar Turizmus Tanszék \\ ccsapo.janos@ktk.pte.hu, dorincz.katalin@gtk.uni-pannon.hu
}

\section{ABSTRACT}

The present publication intends to discuss the economic role of tourism in Hungary between 2000-2019 (pre COVID-19 period), revealing the most important social-economic phenomena until the end of May, 2020 (finishing of the manuscript) and attempts to determine the complex impacts of the crisis and the possible changes in the future of global and domestic tourism as well.

Keywords: tourism, Hungary, economic role, pandemic, projections

\section{BEVEZETÉS}

Globális szinten vizsgálva a turizmus egyrészt a 20. század második felének és a 21. század első két évtizedének egyik legdinamikusabban növekvő gazdasági ágazata, másrészt pedig a lakosság széles körét érintő társadalmi jelenség. Az 1950-es évek óta a világgazdaság új súlypontjainak egyike a szolgáltatás szektor nemzetgazdaságokon belüli látványos növekedése, azon belül pedig a turizmus szerepének folyamatos erősödése (Hall, C. M. 2004, Lew, C. M. et al. 2008, Michalkó G. 2010). Napjainkra a turisztikai világpiac egy összefüggő és egyben kölcsönösen függő rendszert alkot, amelyben a keresleti és a kínálati oldal térben és időben is jelentős változásokon ment keresztül, mind a mennyiségi, mind a minőségi összetevőket tekintve. Még mindig újabb és újabb célterületek (desztinációk) kapcsolódnak be a nemzetközi és a belföldi turizmusba egyaránt, a kiéleződő versenyben pedig csak az a vonzerő, desztináció vagy turisztikai szereplő maradhat talpon, amely és aki a színvonalbeli és mind magasabb minőségi elvárásoknak is megfelel (Töröcsik M. - CsApó J. 2018).

Érdemes továbbá kiemelni, hogy a turizmus regionális kötődése, a lokalitás jelenléte is igen lényeges tényező, mivel a mindenkori attrakciók túlnyomó többsége egy adott hely, térség, természeti táj vonzerőire alapozva jön létre (AUBERT A. et al. 2007, GONDA 
T. - Spiegler P. 2012, Michalkó G. 2012). Azzal pedig, hogy egy térség, lokáció turisztikai kínálatára megfelelő infra- és szuprastruktúra (különböző kategóriájú szállás- és vendéglátóhelyek) kiépítése is megvalósul, az idegenforgalom a területi folyamatok alakítójává is válik. A fenti folyamatok többek között hatnak a településszerkezetre, a foglalkoztatásra, a térségi kapcsolatok alakítására, a környezet formálására, illetve befolyásolják az életmódot, az életminőséget is (Puczkó L. - RÁtz T. 2005, Aubert A. 2010, Bujdosó Z. et al. 2015, Bujdosó Z. 2016, Marton G. et al. 2016).

A legfrissebb adatok tanúsága szerint 2019-re a nemzetközi turistaérkezések (határátlépéssel járó utazások) száma meghaladta az 1,5 milliárd érkezést, amivel párhuzamosan a turisztikai költések 2019-re 1700 milliárd USD értékre növekedtek. A turizmus adta a globális GDP 10,3\%-át, továbbá világszerte 330 millió embernek biztosított munkahelyet, megélhetést, ami az összes munkavállaló mintegy egytized része (UNWTO 2020, WTTC 2020). Ez az elképesztő fejlődés - 1950-ben még összesen 25 millió nemzetközi turistaérkezést regisztráltak (!) - idővel természetesen maga után vonta a turizmus szabályozásának igényét is, hiszen az egyre szembetűnőbb és mindennapjainkban is megélt jelenségek jelentős társadalmi-gazdasági vagy éppen a természetre és - tágabb értelemben - a környezetre gyakorolt hatásokkal bírtak. A negatív hatások kiemelkedő példái közé tartozik a tömegturizmus (angol kifejezéssel: mass tourism) és a hosszú távú tervezést nélkülöző, környezetet romboló, kizárólag a gazdasági érdekekre alapuló turisztikai beruházások, fejlesztések sora.

A hazai viszonyok tekintetében kiemelendő, hogy Magyarország társadalmi-gazdasági életében és nem utolsó sorban nemzetközi imázsában is komoly szerepet tölt be a turizmus. Tanulmányunk ebből a vezérgondolatból kiindulva bemutatja a turizmus 2020 tavaszi világjárvány előtti gazdasági szerepét Magyarországon, feltárja az ágazatban tapasztalt, 2020 májusáig (a kézirat lezárásáig) fellépő jelenségeket. A tanulmány kísérletet tesz annak meghatározására, hogy a COVID-19 okozta válság hatásai miben jelentkeznek, és milyen változásokat hozhatnak a jövő hazai turizmusában.

\section{A TURIZMUS GAZDASÁGI HATÁSAINAK HAZAI TRENDJEI 2000-2019 KÖZÖTT}

Magyarország társadalmi-gazdasági életében már az 1960-as évek végétől komoly szerepet töltött be az idegenforgalom (AUBERT A. - CsAPó J. 2006), amelynek méretét és trendjeit jelen tanulmány a 21. századi folyamatok kapcsán veszi górcső alá a gazdasági hatásokat leginkább jelző turisztikai keresleti mutatók és a makrogazdasági részesedés, hozzájárulás elemzésével.

A turizmus makrogazdasági részesedésének egyik alapvető tényezője a GDP-hez való hozzájárulás, melynek - a World Travel and Tourism Council legújabb iparági 
beszámolója alapján - mértéke hazánkban 2019-ben 8,3\% volt (a világátlag 10,3\%). A turizmusban és vendéglátásban és az ezen ágazatokhoz szorosan köthető ágazatokban dolgozók száma 449200 fö volt, ami az összes foglalkoztatottak 10,0\%-át adja (ez az érték megfelel a világátlagnak). A nemzetközi turizmus által elköltött összeg szintén 2019-ben elérte a 2591 milliárd forintot, ami a teljes export értékének 6,4\%-át teszi ki, ez az érték pedig a szolgáltatásexport 24\%-a (https://wttc.org/Research/Economic-Impact).

$\mathrm{Az}$ ágazaton belüli gazdasági teljesítményt 2000-től vizsgálva a kereskedelmi szálláshelyek forgalma tekintetében megállapítható, hogy annak mértéke a szálláshelyek vendégeinek száma tekintetében (belföldi és külföldi egyaránt) 2000 és 2008 között folyamatos növekedést mutatott, a gazdasági válság hatására pedig 2008-2010 között csökkenést tapasztaltunk, ami viszont 2011-től folyamatos növekedésbe váltott át. A vendégéjszakák forgalma összességében 2000-2005 között, majd egy ugrás után 2006-2008 között lényegében stagnált, aztán a válság generálta 2008-as visszaesés után kedvező értékű növekedést mutatott. A külföldiek által eltöltött vendégéjszakák tekintetében azonban 2000 és 2011 között egy folyamatosan hullámzó tendenciát látunk, ami szintén csak 2011-től mutat folyamatos növekedést, azt viszont egészen 2019-ig (1. ábra).

A hazai kereskedelmi szálláshelyek 2019-ben 12,9 millió vendéget fogadtak, akik összesen 31,5 millió vendégéjszakát töltöttek el. Ezen értékeknek mintegy a felét a

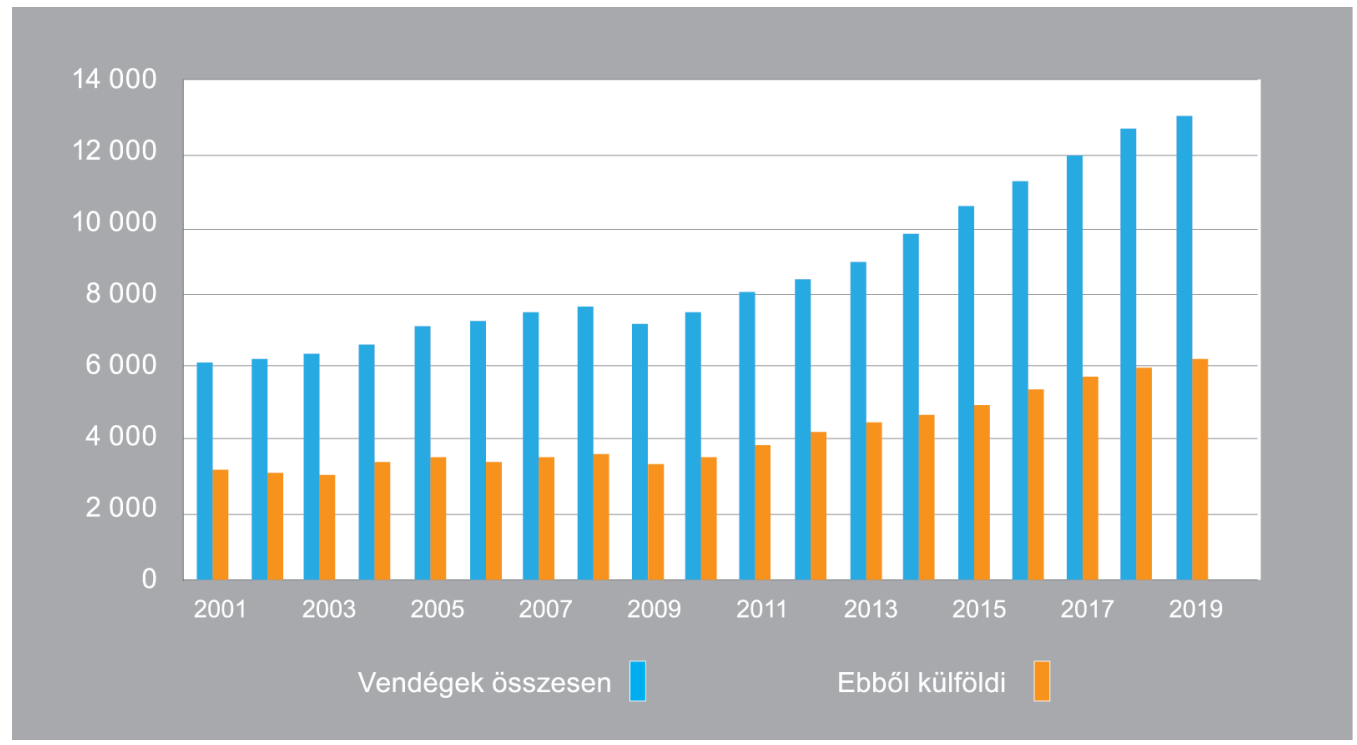

1. ábra. A kereskedelmi szálláshelyek forgalma Magyarországon (vendégek száma) 2001-2019 között (forrás: https://www.ksh.hu/docs/hun/xstadat/xstadat_eves/i_oga002.html) 
külföldi vendégek adják (6,2 millió vendég és 15,8 millió vendégéjszaka). Két fontos tanulságot lehet és kell levonnunk a fenti adatokból: az egyik, hogy hazánkban az átlagos vendégéjszaka szám (2,3-2,4 vendégéjszaka/vendég) még mindig nagyon alacsonynak mondható, illetve azt is figyelembe kell venni, hogy a külföldi vendégek mintegy $60 \%$-a Budapestre koncentrálódik. Ez utóbbi tény hosszú időn keresztül előnye volt a fővárosnak, jelen helyzetben azonban a külföldi vendégek teljes elmaradása miatt egyelöre hátrányává válik. A területi koncentráció mellett fontos felhívni a figyelmet az időbeli koncentrációra is: a vendégforgalom hazánkban a nyári hónapokban meghatározó.

Az üzleti célú egyéb szálláshelyek vendégforgalma tekintetében azt látjuk, hogy 2001től a vendégéjszakák (belföldi, külföldi egyaránt) 2005-ig folyamatosan estek, majd enyhe növekedés volt tapasztalható 2008-ig. Az ezt követö időszakban 2011-ig - a gazdasági válság hatásaként - továbbra is csökkentek az értékek (elérve a 2005-ös mélypontot), amelyek csak 2012 után álltak növekedési pályára. Lényegében ezt az ívet követi a vendégek számának változása is, hiszen 2013-tól folyamatos és tartós növekedés regisztrálható a vendégek és az általuk eltöltött vendégéjszakák számában is egészen 2019-ig (2. ábra).

A Magyarországra tett külföldi utazások száma és a hozzá kapcsolódó kiadások szintén csak 2011-2012-től mutatnak szignifikánsan növekvő értékeket. Az optimista nézőpontot árnyalja azonban, hogy - ahogyan azt már említettük - az átlagos

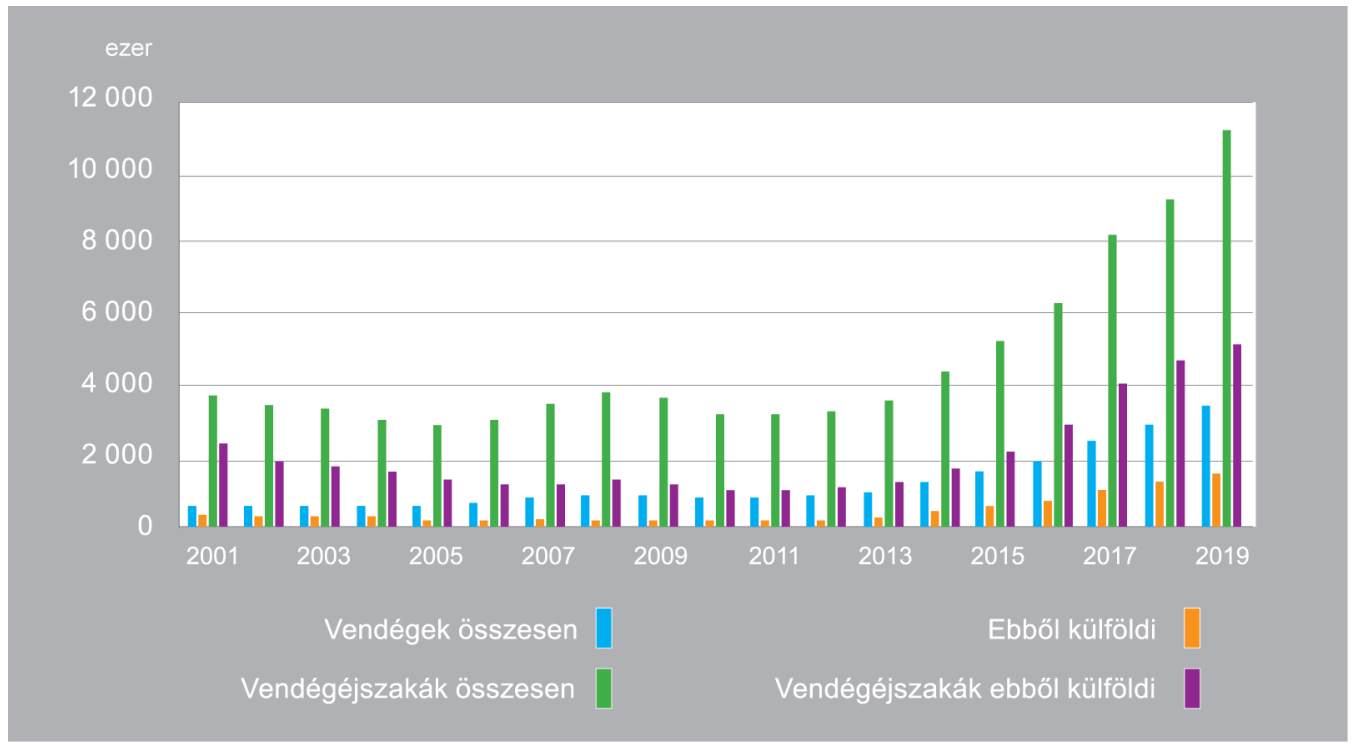

2. ábra. Az üzleti célú egyéb szálláshelyek vendégforgalma Magyarországon 2001-2019 között (forrás: https://www.ksh.hu/docs/hun/xstadat/xstadat_eves/i_oga016.html) 
tartózkodási idő továbbra sem haladta meg a 2,3 napot (2009-ben 2,4 volt). A magyar turisták által külföldre tett utazások száma 2008 után visszaesett, és lényegében csak 2014-től kezdett ismét - 2019-ig folyamatosan - növekedni. A tartózkodási idő és a turisztikai költés pedig a 2011-es komoly visszaesés (51,467 millió napról 43,886 millió napra) után szintén folyamatos növekedést mutatott. 2019-re a hazánkban külföldiek által eltöltött napok száma 45592000 lett, amely során a vendégek összesen 61397 millió Ft-ot költöttek. Az egy före jutó napi költés a külföldi látgatók esetében 2019-ben 16700 Ft volt (https://www.ksh.hu/docs/hun/xstadat/xstadat_eves/i_ogt013.html).

$\mathrm{Az}$ is megfigyelhető, hogy Magyarországon a többnapos belföldi utazások száma 2008 után erősen visszaesett, ami lényegében folyamatosan kitartott 2019-ig az utazással elöltött idő tekintetében is. Ezzel ellentétben elmondható, hogy mind az összes költések, mind pedig az egy före jutó költések mértéke növekedett, bár ez utóbbi még 2019-ben is csak 6634 forint/fő volt, ami a külföldi vendégekhez viszonyítva egyharmadnyi összeget jelent (1. táblázat) (https://www.ksh.hu/docs/hun/xstadat/xstadat_eves/i_ogt009.html).

Összességében elmondható, hogy Magyarország turizmusát még mindig igen erős térbeli és időbeni koncentráció jellemzi. A hazánkba látogató és a belföldi turisták tekintetében is a fö desztinációk Budapest (Közép-Dunavidék) és a Balaton térsége, a szezonalitás mértéke pedig igen magas a nyári föszezon tekintetében. A két kiemelt úticél mellett továbbra is a Nyugat-Dunántúl régió látogatottsági mutatói emelkednek ki, ehhez képest azonban az összes többi turisztikai régió (Közép-Dunántúl, Dél-Dunántúl,

\begin{tabular}{|c|c|c|c|c|}
\hline Év & $\begin{array}{c}\text { Összes utazás } \\
\text { (ezer fö) }\end{array}$ & $\begin{array}{c}\text { Utazással eltöltött idö } \\
\text { (ezer nap) }\end{array}$ & $\begin{array}{c}\text { Költés } \\
\text { (millió Ft) }\end{array}$ & $\begin{array}{c}\text { Egy utazó egy napjára } \\
\text { jutó költés (Ft) }\end{array}$ \\
\hline 2008 & 21494 & 86584 & 290898 & 3360 \\
2009 & 17735 & 72319 & 236818 & 3275 \\
2010 & 17974 & 72463 & 247632 & 3417 \\
2011 & 18798 & 75191 & 263186 & 3500 \\
2012 & 17118 & 70668 & 265797 & 3761 \\
2013 & 14377 & 60935 & 263536 & 4325 \\
2014 & 14854 & 61415 & 294592 & 4797 \\
2015 & 15253 & 61975 & 307407 & 4960 \\
2016 & 14425 & 58967 & 308911 & 5239 \\
2017 & 14374 & 57908 & 328802 & 5678 \\
2018 & 14386 & 60296 & 347421 & 5762 \\
\hline 2019 & 14249 & 59280 & 393243 & 6634 \\
\hline
\end{tabular}

1. táblázat. A többnapos belföldi utazások összefoglaló adatai (2008-2019) (forrás: https://www.ksh.hu/docs/hun/xstadat/xstadat_eves/i_ogt009.html) 


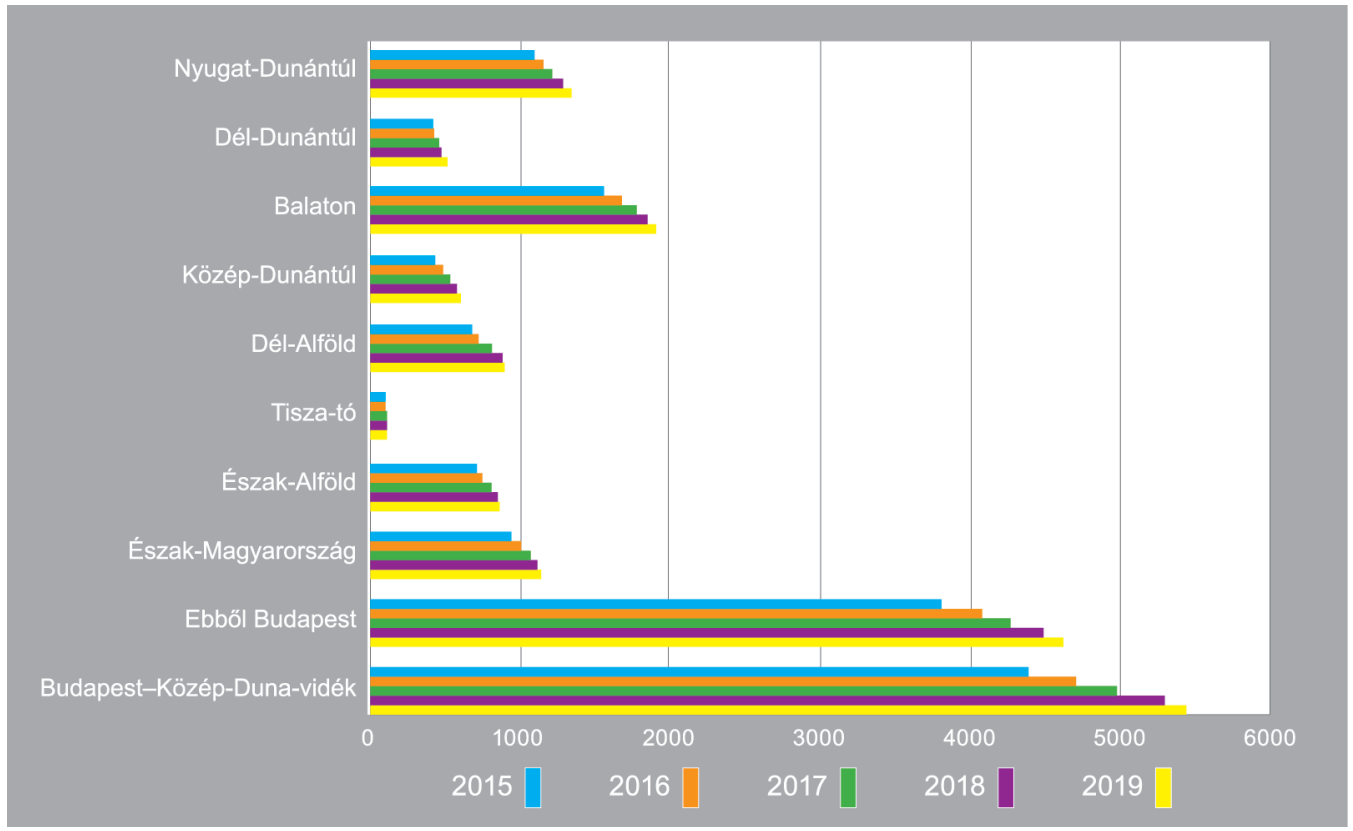

3. ábra. A kereskedelmi szálláshelyek vendégforgalma turisztikai régiónként (vendégek száma 2015-2019, ezerföben) (forrás: https://www.ksh.hu/docs/hun/xstadat/xstadat_eves/i_oga002.html)

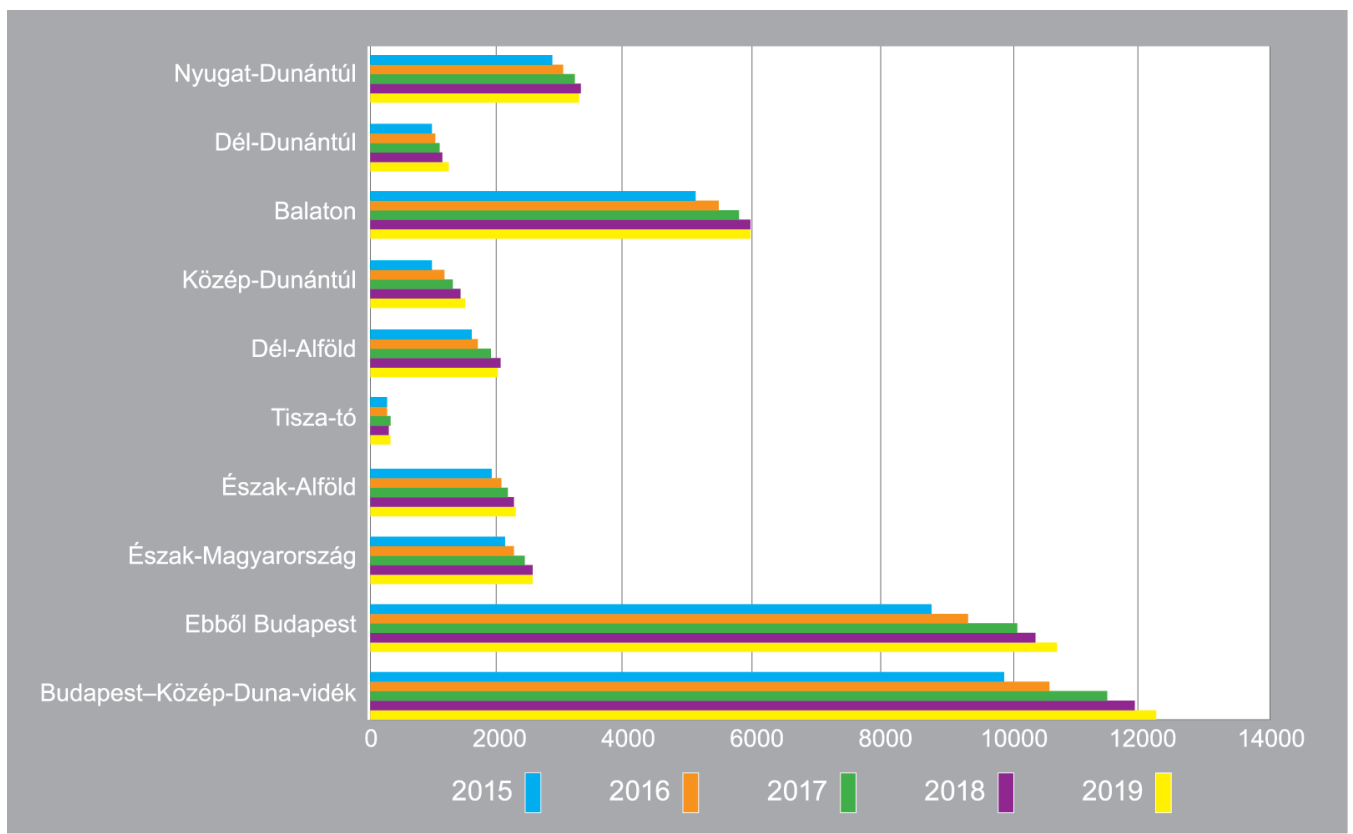

4. ábra. A kereskedelmi szálláshelyek vendégforgalma turisztikai régiónként (vendégéjszakák száma 2015-2019, ezer) (forrás: https://www.ksh.hu/docs/hun/xstadat/xstadat_eves/i_oga002.html) 
Észak-Magyarország, Észak-Alföld, Dél-Alföld, Tisza-tó) forgalma jóval kisebb az előbbiekhez képest (3., 4. ábra).

\section{A 2020. TAVASZI ESEMÉNYEK TURISZTIKAI SZEMPONTÚ ELEMZÉSE}

Magyarországon a COVID-19 miatt kialakult helyzet kapcsán a Kormány 2020. március 11-én vezette be a veszélyhelyzetet (40/2020. [III. 11.] Korm. rendelet veszélyhelyzet kihirdetéséről). Ennek a természetesen szükségszerű lépésnek a turizmusra és vendéglátásra gyakorolt hatása addig soha nem látott, drasztikus visszaesést okozott hazánkban (és a veszélyhelyzet országonkénti kihirdetése kapcsán természetesen a globális turisztikai piacon is), melyet szemléletesen jellemez a 2019. márciusi és 2020. márciusi kereskedelmi szálláshelyeinken regisztrált forgalom mértéke, amely 2019 tárgyhavában 857 514 fö, volt 2020 tárgyhavában pedig 272227 fö (és valószínüsíthető, hogy ezek a turisták még 11-éig érkeztek a szálláshelyekre).

A KSH vonatkozó kimutatásai szerint márciusban a külföldiek által eltöltött vendégéjszakák száma 68\%-kal, az általuk elköltött szállásdíj összege 65\%-kal, a Budapest Liszt Ferenc Nemzetközi Repülőtér utasforgalma pedig 58\%-kal esett vissza az előző évi értékekhez képest (https://www.ksh.hu/docs/hun/xftp/idoszaki/kulf_vendeg_elmaradas/index.html). A külföldi piac kiesésének szerepét szemlélteti az 5. ábra, amely a

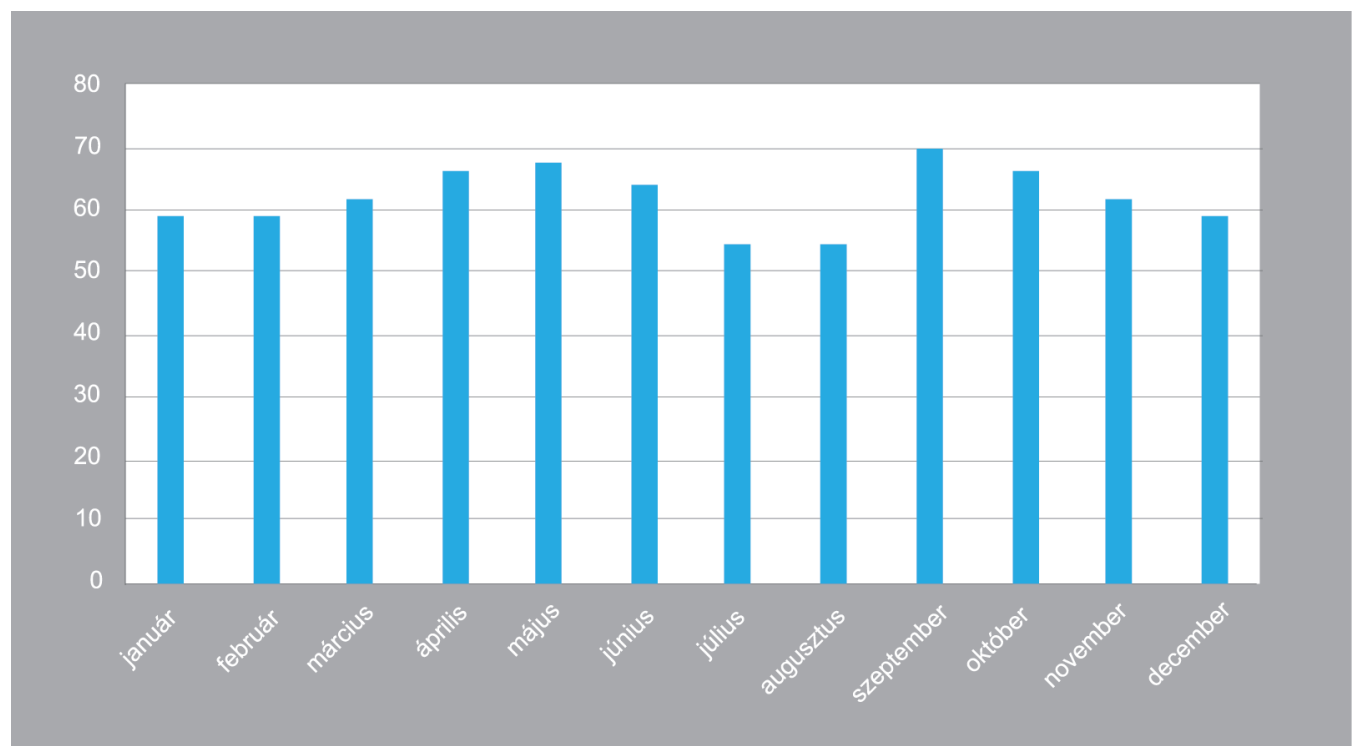

5. ábra. A külföldiek részesedése a havi bruttó szállásdíj bevételböl kereskedelmiszálláshely-típusonként, 2005-2019 átlaga (\%) (forrás: https://www.ksh.hu/docs/hun/xftp/idoszaki/kulf_vendeg_elmaradas/index.html) 
külföldiek részesedését mutatja a havi bruttó szállásdíj bevételből kereskedelmiszálláshely-típusonként. Ezek az adatok alátámasztják a hazai turizmus külföldi piactól függő helyzetét, különös tekintettel a budapesti desztinációban meghatározó szerepére.

Még szembetűnőbb ez a függőség az üzleti célú egyéb szálláshelyek tekintetében, amenynyiben 2019-ben a külföldivendég-éjszakák aránya 47\%-os volt ezen szálláshely-típusnál, Budapest és az e tekintetben legjelentősebb négy vidéki járás (Fonyódi, Hajdúszoboszlói, Keszthelyi, Siófoki) pedig összesen 76\%-os részesedéssel bírt ezen a piacon (https://www. ksh.hu/docs/hun/xftp/idoszaki/kulf_vendeg_elmaradas/index.html).

Összességében tehát a COVID-19-re válaszként hozott óvintézkedések hatásaként Magyarországon az összes turizmushoz köthetö ágazatban drasztikus visszaesés volt tapasztalható: a kereskedelmi szálláshelyeken és az üzleti célú egyéb szálláshelyek tekintetében, a vendéglátóhelyeken, a szórakoztató helyeken, a kiskereskedelemben (határmenti bevásárlóturizmus), az utaztatási piacon, a nemzetközi és regionális repülőterek forgalmában, illetve természetesen a határforgalomban is (eleve a szálláshelyek és a vendéglátó egységek hetekig zárva tartottak).

\section{ELKÉPZELÉSEK A VILÁGJÁRVÁNY UTÁNI IDŐSZAK TURIZMUSÁRÓL}

Természetesen a tanulmány szerzői nem rendelkeznek látnoki képességekkel, így egy tényezőt lehet biztosra venni a turizmus és a hozzá köthető ágazatok jövőbeli trendjei kapcsán: amíg megfelelő gyógyszer vagy vakcina nem áll rendelkezésre (illetve kedvezőbb esetben amíg meg nem szünik maga a vírus), addig csak különböző próbálkozásokról beszélhetünk, az épp aktuális virológiai helyzet által megrajzolt nyitások és zárások hullámzó változásai fognak bekövetkezni. A 2020. április és május hónapokban bekövetkező fokozatos, óvatos nyitás kapcsán azonban leszűrhető néhány új értelmezés, illetve elvárás a hazai turizmus folyamatai kapcsán.

A turisztikai mozgások iránya és motivációja alapján felértékelődnek a belső (hazai) értékek, a közeli helyek, ezáltal a belföldi turizmus erősödhet a nyári hónapokban, hiszen a lakosság túlnyomó részének fontos szükséglete a turizmusban való részvétel (CsAPó J. Gonda T. 2019, Gonda T. et al. 2019). Látni kell azonban, hogy ez a belföldi turizmus, a hétvégi kirándulások száma nem fogja tudni megfelelően kiváltani a beutazó turisztikai keresletet és az abból fakadó bevételeket. Különösen érzékenyen érintettek ebben Budapest és a fürdővárosok (Hévíz, Sárvár, Harkány stb.), így a főváros turisztikai piaca és az egészségturisztikai központok elhúzódó visszaesésre számíthatnak. Ezzel párhuzamosan viszont a vidéki turizmus azon térszínei, helyszínei erősödhetnek meg, ahol eddig az elszigeteltség jelentette a kereslet hiányát, hiszen az elkülönülési vágy (biztonság, kültéri helyszínek és aktivitások) miatt a kirándulók, turisták kereslete megnő ezen úti célok iránt. 
Minden bizonnyal megerősödik a turisták részéről a biztonság iránti igény, ami megmutatkozik majd a higiénia terén (szálláshelyek tisztasága, tányérszervizes étkeztetés preferenciája), a fizikai távolságtartás (social distancing) kapcsán (fürdőhelyek és strandok befogadóképességének szabályozása, fesztiválok és koncertek törlése) és az egyéni vagy kiscsoportos utazásszervezés terén is.

Emellett lényeges piaci stratégia, hogy a szálláshelyek, a légitársaságok vagy az utazási irodák minél rugalmasabb foglalási feltételeket igyekezzenek biztosítani vendégeik számára. A turisztikai szolgáltatóknak rendkívül nagy súlyt kell fektetniük az óvintézkedések kommunikációjára: minden létező fórumon hirdetniük kell, hogy mindent megtettek a biztonságos ott-tartózkodás elérése érdekében.

Egyelöre úgy tünik, hogy Budapest mellett a termál- és gyógyvizekre nagyban építő egészségturizmus helyszínei kerülnek nehéz helyzetbe, hiszen egyelőre még csak a szabadtéri strandok nyitásáról született döntés. Különösen aggasztó ez a fejlemény annak fényében, hogy hazánk legfontosabb turisztikai terméke az egészségturizmus, azon belül pedig a gyógyturizmus.

Arra is látunk esélyt, hogy az elkövetkező időszakban megerősödjön a virtuális turizmus azon ága, ahol az igazi utazást teljes mértékben helyettesíti a virtuális élmény. Ennek legkézenfekvőbb példái a múzeumok, tárlatok, parkok, állatkertek virtuális „bejárása” (VR - virtuális valóság szemüvegekkel, 360 fokos kamera segítségével), de akár természeti értékek megfigyelése, megismerése is szóba jöhet. Itt az erre szakosodott cégek szerepe erösödhet meg.

$\mathrm{Az}$ utolsó tényező a fenntartható(bb) turizmus kialakítása lehet, ami egyrészt annak lesz köszönhetö, hogy a túlturizmus (overtourism) (egykori) helyszínei biztosan megtartják (amíg muszáj lesz) még az óvintézkedések egy részét, tehát nem lesz lehetőség óriási és kezelhetetlen tömegek kialakulására, a desztinációk eltartó képességének túllépésére. Azonban azt is feltételeznünk kell, hogy az elmaradt kereslet miatt - és ezáltal a bevételek mihamarabbi pótlása érdekében - a vírushelyzet megszűnésével nagy az esélye annak, hogy a korábbi túlterhelt turisztikai zónák, a turizmusból élő desztinációk ismét tömeges turisztikai fogyasztást fognak mérni.

\section{ÖSSZEFOGLALÁS}

Magyarország turizmusa az elmúlt évtizedben folyamatosan fejlődésen ment keresztül, ami többek között a gazdasági-társadalmi szerepének erősödésében, illetve egyes turisztikai termékek (egészségturizmus, fesztiválturizmus, rövid tartózkodási idővel járó városi turizmus, bor- és gasztronómia, aktív turizmus) felfutásában, megerősödésében mutatkozik meg. A hazai turizmust mindazonáltal továbbra is erős területi (Budapest, 
Balaton, egészségturisztikai helyszínek) és időbeli (belföld esetén egyértelműen a július és augusztus, hosszú hétvégék) koncentráció jellemzi. A külföldi vendégek elsősorban a fővárost keresik fel és átlagosan háromszor annyit költenek, mint a belföldiek.

A hazai turizmus gyengeségeinek javítása érdekében a közelmúltban megvalósult turisztikai vonzerőfejlesztések (gyógy- és élményfürdők, nemzeti parkok látogatóközpontjai és tanösvényei, kerékpárutak, kulturális- és sportrendezvények, vár- és kastélyprogram), illetve a szálláshelyek szolgáltatásfejlesztései (Kisfaludy Turisztikai Fejlesztési Program, gyógy- és wellness részlegek, konferenciakapacitások, energetika) a föszezon nyújtását, a vidéki helyszínek népszerűségének növelését és a szolgáltatások minőségfejlesztését szolgálták.

A Turisztikai Világszervezet (UNWTO) legutóbbi prognózisa szerint a nemzetközi turizmus bevételei 300-450 milliárd dollárral csökkennek 2020-ban, globális szinten az ágazat teljesítménye csaknem harmadával eshet vissza. A madridi székhelyű szervezet konkrét ajánlásokat fogalmazott meg, amelyek egyrészt segíthetnek a turisztikai ágazatnak a kilábalásban, másrészt ösztönözhetik az utazási hajlandóság helyreállását. A 23 pontból álló dokumentum három fö területtel foglalkozik: (1) válság kezelése és hatásának enyhítése; (2) ösztönzés és a fellendülés felgyorsítása; valamint (3) felkészülés a holnapra (UNWTO, 2020). A turistákat közvetlenül érintő intézkedések közé tartoznak a fogyasztóvédelem és bizalom megteremtése, helyreállítása; a turizmus digitalizációjának erősítése (intelligens piaci rendszerek és digitális eszközök fokozottabb használata a szolgáltatók részéről); a (be)utazások feltételeinek megkönnyítése; valamint a körforgásos gazdaság és a fenntartható turizmus erősítése.

A korábbi válságok tapasztalatai alapján véleményünk szerint a szabadidős turizmus hamarabb állhat helyre, mint az üzleti utazások piaca, és elsőként a családi és baráti látogatások indulhatnak el. A belföldi turizmus, a rövidebb (autós) utazással járó célterületek, illetve a szabadban végezhető aktivitások, rekreációs programok várhatóan keresette(bbe)k lesznek, továbbá a 2020-ban a járványügyi helyzet okán elrendelt (kényszer) szabadságok, rövidített munkaidő és keresetcsökkenés miatt felértékelődnek a hétvégék, ünnepnapok, hosszú hétvégék.

Végezetül a szerzők ki szeretnék emelni, hogy a GeoMetodika megtisztelő felkérésének eleget téve (2020. május végi kéziratzárással) egy olyan tanulmányt igyekeztünk összeállítani, amely felvázolja a hazai turizmus és valamelyest a globális turizmus történeti és aktuális folyamatait, jelenlegi kihívásait, és az arra adható általános érvényűnek tekintett válaszokat, azonban a COVID-19 által okozott világjárvány kapcsán bekövetkező bármilyen (akár pozitív, akár negatív) változás, illetve az erre válaszul adott kormányzati intézkedések ez utóbbiak egy részét természetesen bármikor felülírhatják. 


\section{IRODALOM}

Aubert A. (2010): A globális turizmus jellemzői és trendjei geográfiai megközelítésben. - In: Tóth J. (szerk.): Világföldrajz. Akadémiai Kiadó, Budapest. pp. 646-666.

Aubert A. - Csapó J. (2006): Planning and development aspects of tourism in the regional and rural development programs in Hungary. - In: Ježek, J. (szerk.): New members - new challenges for the European regional development policy. University of Economics in Bratislava, Faculty of Business Economics in Košice. Bratislava. pp. 1-9.

Aubert A. - Csapó J. - Szabó G. (2007): A geográfia és a turizmus területi aspektusai. - In: AUBERT A. (szerk.): A térségi turizmuskutatás és tervezés módszerei, eredményei. Pécsi Tudományegyetem Természettudományi Kar Földrajzi Intézet, Pécs. pp. 133-156.

Aubert A. - Jónás-Berki M. - Marton G. - Pálfi A. (2015): Region specific characters of tourism in East-Central Europe. - Acta Geographica Universitatis Comenianae 59. 1. pp. 21-33.

BujDosó Z. (2016): A turizmus és a területfejlesztés kapcsolatrendszere Magyarországon. - In: Kókai S. (szerk.) A változó világ XXI. századi kihívásai: tanulmánykötet Prof. Dr. Hanusz Árpád egyetemi tanár 70. születésnapja tiszteletére. Nyíregyházi Egyetem Turizmus és Földrajztudományi Intézet, Nyíregyháza. pp. 63-76.

Bujdosó Z. - Dávid L. - Varga D. - Pénzes J. - Gyurkó Á. - Zhakupov, A. (2015): Tourism development and cross-border cooperation in the Hungarian-Romanian border region. - Geojournal of Tourism and Geosites 16. 2. pp. 153-163.

Csapó J. - Gonda T. (2019): A hazai lakosság utazási motivációinak és szokásainak elemzése az aktív turizmus és a fizikai aktivitás tekintetében. - Turisztikai és Vidékfejlesztési Tanulmányok 4. pp. 57-70. https://doi.org/10.15170/TVT.2019.04.04.06

Gonda T. - SpIEgler P. (2012): A turisztikai klaszterek szerepe a regionális marketingben. -Marketing \& Menedzsment 46. 1-2. pp. 15-25.

Gonda T. - NAGy D. - RAfFay Z. (2019): The impact of tourism on the quality of life and happiness. Interdisciplinary Management Research/Interdisziplinare Managementforschung 15. pp. 1790-1803.

Hall, C. M. (2004): Spatial analysis: A critical tool for tourism geographies. - In: Wilson, J. (szerk.): The Routledge handbook of tourism geographies. Routledge, London. pp. 163-173.

Lew, C. M. - Hall, C. M. - Tiмотнy, D. (2008): World geography of travel and tourism: a regional approach. - Elsevier, Oxford. 363 p.

Marton G. - Raffay Z. - PrisztóKa Gy. - Raffay Á. - Kiss R. (2016): A Dráva-mente, mint határmenti, periférikus tér turizmusfejlesztésének problémái. - Turisztikai és Vidékfejlesztési Tanulmányok 1. 2. pp. 34-48.

MichaLкó G. (2010): Boldogító utazás: a turizmus és az életminőség kapcsolatának magyarországi vonatkozásai. - MTA Földrajztudományi Kutatóintézet, Budapest. 119 p.

Michalkó G. (2012): Turizmológia: elméleti alapok. - Akadémiai Kiadó, Budapest. 266 p.

Puczkó L. - RÁtz T. (2005): A turizmus hatásai. - Aula Kiadó, Budapest. 494 p.

TöRőCsıк M. - CsApó J. (2018): Fogyasztói trendek hatása a turizmusra. - In: Csapó J. - Gerdesics V. - Töröcsik M. (szerk.): Generációk a turizmusban. I. Nemzetközi Turizmusmarketing Konferencia, 
Tanulmánykötet. Pécsi Tudományegyetem Közgazdaságtudományi Kar, Pécs. pp. 8-22.

40/2020. (III. 11.) Korm. rendelet veszélyhelyzet kihirdetéséről (https://net.jogtar.hu/jogszabaly?docid=A2000040.KOR) (utolsó letöltés 2020. 06. 22.)

UNWTO, 2020: Covid-19 Tourism Recovery Technical Assistance Package, 27 p. https://webunwto. s3.eu-west-1.amazonaws.com/s3fs-public/2020-05/COVID-19-Tourism-Recovery-TA-Package_8\%20 May-2020.pdf (utolsó letöltés: 2020. 06. 22.)

UNWTO, 2020: https://www.e-unwto.org/doi/abs/10.18111/wtobarometereng.2020.18.1.1 (utolsó letöltés: 2020. 06. 22.)

WTTC, 2020: https://wttc.org/Research/Economic-Impact (utolsó letöltés: 2020. 06. 22.)

https://www.ksh.hu/docs/hun/xstadat/xstadat_eves/i_oga002.html (utolsó letöltés: 2020. 06. 22.)

https://www.ksh.hu/docs/hun/xstadat/xstadat_eves/i_oga016.html (utolsó letöltés: 2020. 06. 22.)

https://www.ksh.hu/docs/hun/xstadat/xstadat_eves/i_ogt013.html (utolsó letöltés: 2020. 06. 22.)

https://www.ksh.hu/docs/hun/xstadat/xstadat_eves/i_ogt009.html (utolsó letöltés: 2020. 06. 22.)

https://www.ksh.hu/docs/hun/xstadat/xstadat_eves/i_oga002.html (utolsó letöltés: 2020. 06. 22.)

https://www.ksh.hu/docs/hun/xftp/idoszaki/kulf_vendeg_elmaradas/index.html (utolsó letöltés: 2020. 06. 22.) 